\title{
Peran Kualitas Pelayanan dan Kualitas Produk Terhadap Keputusan Konsumen dalam Penggunaan Gas PGN Pada Masyarakat Kota Batam
}

\author{
Hendri Herman, Vargo Christian L. Tobing \\ Universitas Putera Batam, Indonesia \\ Email author: hendrihermanbatam@gmail.com/vargo.tobing@gmail.com
}

\begin{abstract}
ABSTRAK
Penelitian ini memiliki tujuan untuk mengetahui peran kualitas pelayanan dan kualitas produk terhadap keputusan konsumen dalam menggunakan gas PGN pada masyarakat kota Batam. Responden dalam penelitian ini adalah masyarakat rumah tangga yang telah menggunakan gas PGN dengan total responden sebesar 98 responden. Data dalam penelitian ini diperoleh dengan melakukan penyebaran kuisioner kepada responden. Data yang telah terkumpul akan ditabulasi untuk kemudian diolah dengan menggunakan program olah data SPSS. Dari hasil penelitian, diketahui bahwa kualitas pelayanan memiliki pengaruh signifikan terhadap keputusan konsumen, begitu juga dengan kualitas produk memiliki pengaruh signifikan terhadap keputusan konsumen, dan secara simultan, kualitas pelayanan dan kualitas produk berpengaruh signifikan terhadap keputusan konsumen. Jika dibandingkan dengan kualitas pelayanan, kualitas produk memiliki pengaruh yang besar terhadap keputusan konsumen. Nilai $\mathrm{R}$ square sebesar 22,8\% yang berarti kualitas pelayanan dan kualitas produk mampu mempengaruhi keputusan konsumen dalam penggunaan gas PGN sebesar 22,8\%.
\end{abstract}

Kata Kunci: Kualitas pelayanan; kualitas produk; keputusan konsumen

\section{PENDAHULUAN}

Keputusan pemerintah untuk mengkonversi penggunaan gas dari penggunaan gas LPG menjadi gas PGN sebagai bahan bakar pengganti tentu sudah melalui berbagai kajian baik dari segi plus dan minus-nya. Gas bumi itu sendiri disupply oleh PT Perusahaan Gas Negara (Persero) Tbk (PGN), PGN dinilai sangat membantu dan hemat dalam pengeluaran rumah tangga.

Kelemahan penggunaan gas LPG yang selama ini dialami oleh pengguna gas LPG adalah terkadang pengguna gas LPG mengalami kesulitan untuk memperoleh gas LPG sementara gas tersebut sangat dibutuhkan dalam kehidupan berumah tangga untuk memasak makanan yang akan dikonsumsi. Akibat kesulitan memperoleh gas LPG ini, maka tidak jarang masyarakat mengalami masalah saat akan memasak. Jika saat gas LPG sulit untuk didapatkan, maka tidak sedikit agenagen gas LPG menaikkan harga jual sehingga kondisi ini akan menambah beban bagi masyarakat.

Keinginan masyarakat untuk beralih dari penggunaan gas LPG ke gas PGN tentu dikarenakan oleh berbagai pertimbangan. Kualitas pelayanan dan kualitas produk tentu menjadi sebagian hal yang dipertimbangkan masyarakat. Kualitas 
merupakan suatu kondisi dinamis yang berhubungan dengan produk, jasa, manusia, proses, dan lingkungan yang memenuhi atau melebihi harapan (Goetsch \& David, 1994 dalam Tangkilisan (2007).

Pelayanan yang berkualitas tinggi mencakup harapan agar pemerintah dalam hal ini Perusahaan Gas Negara (PGN) dapat memberikan pelayanan yang efisien, tepat waktu, dan terpercaya. Kualitas pelayanan secara khusus berkaitan dengan tingkat kepuasan masyarakat terhadap pelayanan yang diberikan. Masyarakat tentu mengharapkan pelayanan yang lebih baik lagi jika masyarakat sudah beralih dari penggunaan gas LPG ke gas PGN

Peralihan dari gas LPG ke gas PGN tentu dikarenakan gas PGN memiliki kelebihan dan kualitas yang baik dibandingkan dengan gas LPG. Gas dengan penggunaan gas PGN akan lebih aman dibandingkan dengan penggunaan gas LPG. Sebagaimana yang diketahui, penggunaan gas LPG sering sekali terjadi kebocoran pada gas sehingga menyebabkan tabung gas meledak bahan menyebabkan terjadinya kebakaran. Dengan penggunaan gas PGN ini, kemungkinan buruk tersebut dapat dihindari. Selain itu, biaya yang dikeluarkan untuk gas PGN jauh lebih murah dibandingkan dengan gas LPG.

Kualitas produk itu sendiri dapat dikatakan baik apabila fungsi dari produk tersebut dapat memenuhi kebutuhan konsumen atas produk tersebut. Assauri (2010) mendefenisikan bahwa kualitas produk merupakan hal yang perlu mendapat perhatian utama dari perusahaan/ produsen. Kualitas merupakan satu dari alat utama untuk mencapai posisi produk. Kualitas menyatakan tingkat kemampuan dari suatu merek atau produk tertentu dalam melaksanakan fungsi dan harapan. Kualitas produk menunjukkan ukuran tahan lamanya produk itu, dapat dipercayainya produk tersebut, ketepatan produk, mudah mengoperasikan dan memeliharanya serta atribut lain yang dinilai.

\section{KAJIAN TEORI}

\section{Kualitas Pelayanan}

Dalam dunia bisnis, bukan hanya produk/ jasa yng diperhatikan. Dalam hal berbisnis kualitas pelayanan harus bias diperhatikan juga.karena kualitas pelayanan merupakan cara mempertahankan pelanggan. Dengan adanya kualitas, berarti perusahaan harus memenuhi harapan-harapan pelanggan dan memuaskan kebutuhan mereka.

Kualitas layanan adalah suatu tindakan yang dilakukan untuk memenuhi kebutuhan orang lain (konsumen, nasabah, tamu, klien, pasien, penumpang, dan lain- lain) yang tingkat pemuasnya hanya dapat dirasakan oleh orang yang melayani maupun yang dilayani. Dalam hal ini terjadi komunikasi batin antara keduabelah pihak dan kepuasan yang diperoleh tergantung pada situasi saat terjadinya interaksi pelayanan tersebut (Kotler,1990: 36 dalam (Utomo, 2009) 


\section{Indikator Kualitas Pelayanan}

Indikator kualitas pelayanan (Tjiptono dan Chandra, 2005) dalam Rezha (2013) adalah sebagai berikut:

1. Reliabilitas

2. Daya tanggap

3. Empati

4. Bukti fisik

\section{Kualitas Produk}

Menurut Kotler (2009) kualtias didefenisikan sebagai keseluruhan ciri serta sifat barang dan jasa yang berpengaruh pada kemampuan meenuhi kebutuhan yang dinyatakan maupun yang tersirat. Untuk mencapai kualitas produk yang diinginkan maka diperlukan suatu standarisasi kualitas. Cara ini dimaksudkan untuk menjaga agar produk yang dihasilkan memenuhi standar yang telah ditetapkan sehinga konsumen tidak akan kehilangan kepercayaan terhadap produk yang bersangkutan.

Kualitas produk adalah suatu kondisi dinamis yang berhubungan dengan produk, jasa, manusia, proses, dan lingkungan yang memenuhi atau melebihi harpan (tjiptono dalam (Windarti \& Ibrahim, 2017)

Kualitas produk merupakan kemampuan sebuah produk dalam memperagakan fungsinya, hal ini termasuk keseluruhan durabilitas, reliabilitas, ketepatan, kemudahan pengoperasian, dan reparasi produk, juga atribut produk lainnya (Kotler, 2012).

\section{Indikator Kualitas Produk}

Indikator kualitas produk (Mowen \& Minor, 2012) adalah:

1. Kinerja

Kinerja disini adalah kinerja utama dari karakteristik pengoperasian produk

2. Reliabilitas atau keandalan

Reliabilitas adalah konsistensi kinerja produk. Bebas dari kerusakan atau tidak berfungsi

3. Daya tahan

Rentang kehidupan produk/ umur pemakaian produk

4. Keamanan

Produk yang tidak aman merupakan produk yang mempunyai kualitas yang kurang/ rendah

\section{Keputusan Konsumen}

Keputusan membeli seseorang merupakan hasil suatu hubungan yang saling memengaruhi dan yang rumit antara factor-faktor budaya, social, pribadi, dan psikologi. Banyakdari faktor ini tidak banyak dipengaruhi oleh pemasar. Namun 
faktor-faktor ini sangat berguna untuk mengindentifikasi pembeli-pembeli yang mungkin memiliki minat terbesar terhadap suatu produk (Setiadi, Nugroho, 2013).

\section{Tahap-Tahap Keputusan Pembelian Konsumen}

Berikut adalah tahap-tahap keputsan pembelian konsumen (Setiadi, Nugroho, 2013):

1. Pengenalan masalah

Proses membeli diawali saat pembeli menyadari adanya masalah kebutuhan. Pembeli menyadari terdapat perbedaan antara kondisi sesungguhnya dan kondisi yng diinginkannya.

2. Pencarian informasi

Seorang konsumen yang mulai timbul minatnya akan terdorong untuk mencari informasi lebih banyak.

3. Evaluasi alternative

Bagaimana konsumen memproses informasi tentang pilihan merek untuk membuat keputusan akhir

4. Keputusan membeli

Konsumen membentuk preferensi terhadap merek-merek yang terdapat pada perangkat pilihan. Konsumen mungkin juga membentuk tujuan membeli untuk merek yang paling disukai.

5. Perilaku sesudah pembelian

Sesudah pembelian terhadap suatu produk yng dilakukan konsumen akan mengalami beberapa tingkat kepuasan atau ketidakpuasan. Konsumen tesebut juga kan terlibat dalam tindakan sesudah pembelian dan penggunaan produk yang akan menarik minat pemasar

6. Kepuasan sesudah pembelian

Sesudah membeli suatu produk, seorang konsumen mungkin mendeteksi adanya suatu cacat. Beberapa pembeli tidak akan menginginkan produk cacat tersebut, yang lainnya akan bersifat netral dan beberapa bahkan mungkin melihat cacat itu sebagai sesuatu yang meningkatkan nilai dari produk

7. Tindakan sesudah pembelian

Kepuasan atau ketidakpuasan konsumen pada suatu produk akan memengaruhi tingkah laku berikutnya. Jika konsumen merasa puasa, maka ia akan memperlihatkan kemungkinan yang lebih tinggi untuk membeli produk itu lagi.

8. Penggunaan dan pembuangan sesudah pembelian

Para pemasar juga harus mengontrol bagaimana pembeli menggunakan dan membuang suat produk. Bila konsumen menemukan cara pemakaian penggunaan baru ini haruslah menarik minat pemasar karena penggunaan baru tersebut dapat diiklankan. 


\section{Indikator Keputusan Konsumen}

Menurut Suwandari dalam (Nasution \& Yasin, 2014) yang menjadi indikator minat beli seorang calon konsumen adalah sebagai berikut:

1. Attention

Perhatian calon konsumen terhadap produk yang ditawarkan oleh produsen

2. Interest

Ketertarikan calon konsumen terhadap produk yang ditawarkan oleh produsen

3. Desire

Keinginan calon konsumen untuk memiliki produk yang ditawarkan oleh produsen

4. Action

Calon konsumen melakukan pembelian terhadap produk yang ditawarkan

\section{Hipotesis Penelitian}

Hipotesis dalam penelitian ini sebagai berikut:

1. Kualitas pelayanan berpengaruh signifikan terhadap keputusan konsumen

2. Kualitas produk berpengaruh signifikan terhadap keputusan konsumen

3. Kualitas pelayanan dan kualitas produk secara simultan berpengaruh signifikan terhadap keputusan konsumen

\section{METODE PENELITIAN}

Jenis penelitian ini adalah deskriptif kuantitatif. Responden dalam penelitian ini adalah masyarakat rumah tangga yang telah menggunakan gas PGN dengan jumlah sampel sebesar 98 responden. Teknik analisis data yang digunakan dalam penelitian ini yaitu; uji validitas, uji reliabilitas, uji normalitas, uji multikolinearitas, uji heteroskedastisitas, analisis regresi berganda, analisis korefisien determinasi dan uji hipotesis, baik secara parsial maupun secara simultan.

\section{TEMUAN DAN PEMBAHASAN}

\section{Uji Validitas}

Hasil uji validitas kualitas pelayanan dapat dilihat pada tabel berikut:

\begin{tabular}{llllll}
\hline No & & Item & R Hitung & R Tabel & Kesimpulan \\
\hline 1 & X1.1 & 0,859 & 0,1986 & Valid \\
2 & X1.2 & 0,854 & 0,1986 & Valid \\
3 & X1.3 & 0,801 & 0,1986 & Valid \\
4 & X1.4 & 0,780 & 0,1986 & Valid \\
\hline
\end{tabular}


Dari tabel di atas, terlihat bahwa pearson correlation ( $\mathrm{R}$ hitung) untuk masingmasing item dalam variable kualitas pelayanan lebih besar dari nilai $R$ tabel $(0,1986)$ Maka dapat disimpulkan bahwa, seluruh item yang ada dalam variable kualitas pelayanan adalah valid.

Hasil uji validitas kualitas produk dapat dilihat pada tabel berikut:

\begin{tabular}{|c|c|c|c|c|}
\hline No & Item & R Hitung & R Tabel & Kesimpulan \\
\hline 1 & $\mathrm{X} 2.1$ & 0,782 & 0,1986 & Valid \\
\hline 2 & X2.2 & 0,663 & 0,1986 & Valid \\
\hline 3 & X2.3 & 0,800 & 0,1986 & Valid \\
\hline 4 & X2.4 & 0,744 & 0,1986 & Valid \\
\hline
\end{tabular}

Dari tabel di atas, terlihat bahwa pearson correlation ( $\mathrm{R}$ hitung) untuk masingmasing item dalam variable kualitas produk lebih besar dari nilai $R$ tabel $(0,1986)$. Maka dapat disimpulkan bahwa seluruh item dalam variable kualitas produk adalah valid. Hasil uji validitas keputusan konsumen kredit dapat dilihat pada tabel berikut:

\begin{tabular}{llllll}
\hline No & & Item & R Hitung & R Tabel & Kesimpulan \\
\hline 1 & Y.1 & & 0,757 & 0,1986 & Valid \\
2 & Y.2 & 0,835 & 0,1986 & Valid \\
3 & Y.3 & 0,827 & 0,1986 & Valid \\
4 & Y.4 & 0,720 & 0,1986 & Valid \\
\hline
\end{tabular}

Dari tabel di atas, dapat dilihat bahwa nilai $\mathrm{R}$ hitung dari masing-masing item keputusan konsumen memiliki nilai yang lebih besar dari nilai $R$ tabel $(0,1986)$. Maka dapat disimpulkan bahwa semua item dalam keputusan konsumen adalah valid.

\section{Uji Reliabilitas}

Hasil uji reliabilitas dapat dilihat pada tabel berikut ini:

\begin{tabular}{lll}
\hline Variabel & Cronbach Alpha & Keterangan \\
\hline Kualitas pelayanan & 0,834 & Reliabel \\
Kualitas produk & 0,738 & Reliabel \\
Keputusan konsumen & 0,792 & Reliabel \\
\hline
\end{tabular}

Dari tabel di atas, terlihat bahwa masing-masing variabel memiliki nilai Cronbach Alpha lebih besar dari 0,6. Sehingga dapat diambil kesimpulan bahwa alat ukur yang digunakan dalam penelitian ini adalah reliabel 


\section{Uji Normalitas}

Hasil uji normalitas dapat dilihat pada tabel berikut:

\begin{tabular}{llr}
\hline \multicolumn{2}{c}{ One-Sample Kolmogorov-Smirnov Test } \\
\hline $\mathrm{N}$ & & $\begin{array}{c}\text { Unstandardized } \\
\text { Residual }\end{array}$ \\
\hline Normal Parameters ${ }^{\mathrm{a}, \mathrm{b}}$ & Mean & 98 \\
& Std. Deviation & .0000000 \\
& Absolute & 1.70812672 \\
Most Extreme Differences & Positive & .081 \\
& Negative & .043 \\
Kolmogorov-Smirnov Z & & -.081 \\
Asymp. Sig. (2-tailed) & .804 \\
\hline a. Test distribution is Normal. & .538 \\
\hline b. Calculated from data. & \\
\hline
\end{tabular}

Dari tabel Kolmogorov smirnov di atas, dapat dilihat bahwa nilai signifikan sebesar 0,538. Nilai signifikansi ini lebih besar dari 0,05. Sehingga dapat diambil kesimpulan bahwa data dalam penelitian ini telah terdistribusi secara normal.

\section{Uji Multikolinearitas}

Hasil uji multikolinearitas dapat dilihat pada tabel berikut:

\begin{tabular}{|c|c|c|c|}
\hline \multicolumn{4}{|c|}{ Coefficients $^{\mathrm{a}}$} \\
\hline \multirow[t]{2}{*}{ Model } & & \multicolumn{2}{|c|}{ Collinearity Statistics } \\
\hline & & Tolerance & VIF \\
\hline \multirow{2}{*}{1} & Kualitas Pelayanan & .885 & 1.130 \\
\hline & Kualitas Produk & .885 & 1.130 \\
\hline
\end{tabular}

a. Dependent Variable: Keputusan Konsumen

Dari tabel di atas, dapat dilihat bahwa kualitas pelayanan memiliki nilai VIF sebesar 1,130 dan nilai VIF kualitas produk sebesar 1,130. Nilai VIF ini lebih kecil dari 10. Sehingga dapat diambil kesimpulan bahwa antara variable bebas di dalam penelitian ini, tidak terjadi multikolinearitas. 


\section{Uji Heteroskedastisitas}

Hasil uji heteroskedastisitas dapat dilihat pada tabel berikut:

\begin{tabular}{|c|c|c|c|c|c|c|}
\hline \multicolumn{7}{|c|}{ Coefficients ${ }^{a}$} \\
\hline \multirow[t]{2}{*}{ Model } & & Unstandardize & Coefficients & Standardized & $t$ & Sig. \\
\hline & & B & Std. Error & Beta & & \\
\hline \multirow{3}{*}{1} & (Constant) & 1.003E-013 & 1.838 & & .000 & 1.000 \\
\hline & Kualitas Pelayanan & .000 & .083 & .000 & .000 & 1.000 \\
\hline & Kualitas Produk & .000 & .099 & .000 & .000 & 1.000 \\
\hline
\end{tabular}

a. Dependent Variable: ABS_RES

Dari tabel di atas, dapat dilihat bahwa kualitas pelayanan dan kualitas produk memiliki nilai signifikan sebesar 1,000. Nilai signifikan ini lebih besar dari 005 sehingga dapat diambil kesimpulan bahwa, dalam penelitian ini tidak terjadi masalah heteroskedastisitas

\section{Analisis Koefisien Determinasi}

Hasil analisis koefisien regresi berganda dapat dilihat pada tabel berikut ini:

\begin{tabular}{lcccc}
\hline \multicolumn{4}{c}{ Model Summary } \\
\hline Model & R & R Square & $\begin{array}{c}\text { Adjusted R } \\
\text { Square }\end{array}$ & $\begin{array}{c}\text { Std. Error of } \\
\text { the Estimate }\end{array}$ \\
\hline 1 & $.477^{\mathrm{a}}$ & .228 & .211 & 1.726 \\
\hline a. Predictors: (Constant), Kualitas Produk, Kualitas Pelayanan \\
\hline \multicolumn{4}{l}{ b. Dependent Variable: Keputusan Konsumen } \\
\hline
\end{tabular}

Dari tabel di atas, dapat dilihat bahwa nilai $\mathrm{R}$ square sebesar 0,228 atau $22,8 \%$ yang memiliki arti bahwa kualitas pelayanan dan kualitas produk mampu mempengaruhi keputusan konsumen sebesar 22,8\%.

\section{Uji Hipotesis}

Uji T (Uji Parsial)

Hasil uji hipotesis secara parsial dapat dilihat pada tabel berikut:

\begin{tabular}{|c|c|c|c|c|c|c|}
\hline \multicolumn{7}{|c|}{ Coefficients ${ }^{a}$} \\
\hline \multirow[t]{2}{*}{ Model } & & Unstandardize & Coefficients & Standardized & $\mathrm{t}$ & Sig. \\
\hline & & B & Std. Error & Beta & & \\
\hline \multirow{3}{*}{1} & (Constant) & 7.930 & 1.838 & & 4.315 & .000 \\
\hline & Kualitas Pelayanan & .267 & .083 & .310 & 3.239 & .002 \\
\hline & Kualitas Produk & .280 & .099 & .272 & 2.836 & .006 \\
\hline
\end{tabular}

a. Dependent Variable: Keputusan Konsumen

Dari tabel di atas, dapat diketahui bahwa:

1. Kualitas pelayanan memiliki pengaruh yang signifikan terhadap keputusan konsumen 
Kualitas pelayanan memiliki nilai signifikan sebesar 0,002. Nilai signifikan ini lebih kecil dari 0,05. Sehingga dapat ditarik kesimpulan bahwa kualitas pelayanan berpengaruh signifikan terhadap keputusan konsumen.

2. Kualitas produk memiliki pengaruh yang signifikan terhadap keputusan konsumen

Kualitas produk memiliki nilai signifikan sebesar 0,006. Nilai signifikan ini lebih kecil dari 0,05. Sehingga dapat ditarik kesimpulan bahwa kualitas produk berpengaruh signifikan terhadap keputusan konsumen.

\section{Uji F (Uji Simultan)}

Hasil uji hipotesis secara simultan dapat dilihat pada tabel berikut:

\begin{tabular}{|c|c|c|c|c|c|c|}
\hline \multicolumn{7}{|c|}{ ANOVA $^{a}$} \\
\hline Model & & $\begin{array}{l}\text { Sum of } \\
\text { Squares }\end{array}$ & $\mathrm{df}$ & Mean Square & $\mathrm{F}$ & Sig. \\
\hline \multirow{3}{*}{1} & Regression & 83.392 & 2 & 41.696 & 13.996 & $.000^{\mathrm{b}}$ \\
\hline & Residual & 283.017 & 95 & 2.979 & & \\
\hline & Total & 366.408 & 97 & & & \\
\hline
\end{tabular}

Dari tabel di atas, diketahui bahwa:

1. Secara simultan kualitas pelayanan dan kualitas produk berpengaruh signifikan terhadap keputusan konsumen

Berdasarkan tabel di atas, dapat dilihat bahwa nilai signifikan sebesar 0,000. Nilai signifikan ini lebih kecil dari 0,05. Sehingga dapat ditarik kesimpulan bahwa secara simultan, kualitas pelayanan dan kualitas produk berpengaruh signifikan terhadap keputusan konsumen.

\section{PEMBAHASAN}

Kualitas pelayanan berpengaruh signifikan terhadap keputusan konsumen Dari hasil penelitian diketahui bahwa kualitas pelayanan memiliki pengaruh yang signifikan terhadap keputusan konsumen dalam menggunakan gas PGN kota Batam. Pelayanan merupakan kegiatan membantu dalam penyediaan segala sesuatu yang dibutuhkan oleh orang lain, termasuk didalamnya konsumen. Pelayanan yang baik tentu akan membantu konsumen dalam menyelesaikan permasalahan yang dialami dan membuat konsumen merasa dihargai.

Perusahaan sebagai penyedia produk/ jasa yang ditawarkan kepada masyarakat tentu harus memperhatikan pelayanan yang akan diberikan kepada konsumen. Perusahaan harus memberikan pelayanan yang berkualitas. Pelayanan dikatakan berkualitas apabila perusahaan memiliki karyawan yang berkualitas, perusahaan memiliki sarana dan prasarana yang lengkap, perusahaan bertanggungjawab kepada setiap pelanggan, memberikan pelayanan secara cepat 
dan tepat, perusahaan memiliki karyawan yang mampu berkomunikasi dengan baik, karyawan perusahaan harus memahami dan mengetauhi tentang produk yang ditawarkan kepada konsumen, memahami kebutuhan pelanggan.

Dari hasil kuisioner yang telah diberikan kepada responen, diketahui bahwa PGN telah memberikan pelayanan yang diharapkan oleh konsumen, karyawan perusahaan sangat membantu dalam penyelesaian keluhan pelanggan, perusahaan mengutamakan kepentingan konsumen, serta perusahaan telah memiliki teknologi yang baik dalam memberikan pelayanan.

Hasil penelitian ini sejalan dengan penelitian yang dilakukan oleh (Mukti, 2015) yang menyatakan bahwa kualitas pelayanan berpengaruh signifikan terhadap keputusan konsumen.

Kualitas produk berpengaruh signifikan terhadap keputusan konsumen. Dari hasil penelitian, diketahui bahwa kualitas produk memiliki pengaruh signifikan terhadap keputusan konsumen dalam memutuskan untuk menggunakan gas PGN. kualitas produk menjadi faktor penentu tingkat kepuasan yang diperoleh konsumen setelah melakukan pembelian dan pemakaian terhadap suatu produk/ jasa. Produk dikatakan berkualitas apabila produk tersebut mampu melaksanakan fungsinya seperti daya tahan, keandalan, ketepatan, kemudahan operasi dan perbaikan serta atribut bernilai lainnya.

Dilihat dari hasil penelitian, kualitas produk memiliki pengaruh yang besar terhadap keputusan konsumen dalam mengambil keputusan untuk menggunakan gas PGN dengan nilai koefisien 0,280. Hal ini berarti, perusahaan harus tetap menjaga kualitas produk mereka agar konsumen tetap setia menggunakan produk.

Dari hasil kuisioner yang telah diberikan kepada responden, diketahui bahwa penggunaan gas PGN lebih irit sehingga dapat masyarakat dapat menghemat, masyarakat menyetujui jika dengan menggunakan gas PGN, masyarakat mendapatkan banyak kemudahan karena tidak perlu khawatir jika kehabisan gas seperti penggunaan pada gas tabung (LPG), penggunaan gas dapat digunakan dalam jangka waktu yang lama, dan konsumen juga mengakui jika dengan menggunakan gas PGN lebih aman.

Hasil penelitan ini sejalan dengan penelitian yang dilakukan oleh (Sunarto, 2015) yang menyatakan bahwa kualitas produk berpengaruh terhadap keputusan pembelian konsumen.

Kualitas Pelayanan dan Kualitas Produk Secara Simultan Berpengaruh Signifikan Terhadap Keputusan Konsumen. Dari hasil penelitian diketahui bahwa kualitas pelayanan dan kualitas produk mempengaruhi keputusan konsumen dalam menggunakan gas PGN. Kualitas pelayanan dan kualitas produk tentu harus menjadi perhatian penting bagi perusahaan sebagai penyedia produk. Produk dan pelayanan yang berkualitas menjadi penentu konsumen dalam memutuskan untuk melakukan pembelian. 
Dari hasil kuisioner yang telah diberikan kepada responden, diketahui bahwa konsumen sudah memperoleh informasi yang cukup mengenai produk sebelum memutuskan untuk menggunakan gas PGN, konsumen tertarik dengan produk yang dihasilkan oleh PGN, konsumen memutuskan menggunakan gas PGN karena kelebihan dari produk tersebut yang tidak dimiliki oleh produk lain, dan produk gas yang dihasilkan oleh PGN adalah produk yang dibutuhkan konsumen.

\section{KESIMPULAN DAN SARAN}

Dari hasil penelitian yang telah dilakukan, maka dapat disimpulkan sebagai berikut:

1. Kualitas pelayanan berpengaruh signifikan terhadap keputusan konsumen dalam menggunakan gas PGN.

2. Kualitas produk berpengaruh signifikan terhadap keputusan konsumen dalam menggunakan gas PGN

3. Secara simultan, kualitas pelayanan dan kualitas produk berpengaruh signifikan terhadap keputusan konsumen dalam menggunakan gas PGN

4. Kualitas produk memiliki pengaruh yang lebih besar dibandingkan kualitas pelayanan dengan nilai koefisien regresi sebesar 0,280

Adapun saran dari hasil penelitian yang telah dilakukan adalah:

1. Dikarenakan kualitas pelayanan mempengaruhi keputusan konsumen, maka perusahaan diharapkan tetap dapat memberikan pelayanan yang terbaik kepada konsumen

2. Dikarenakan kualitas produk mempengaruhi keputusan konsumen, maka perusahaa diharapkan dapat tetap menjaga dan meningkatkan kualitas produk

\section{DAFTAR PUSTAKA}

Assauri, S. (2010). Manajemen Pemasaran. Raja Grafindo Persada.

Kotler., K. (2009). Manajemen Pemasaran (12th, Jilid ed.). Indeks.

Kotler. (2012). Principles of marketing: an Asian perspective. Pearson Prentice.

Mowen, J. C., \& Minor, M. (2012). Perilaku Konsumen. Jilid 1, Edisi Kelima. Erlangga.

Mukti, M. Y. D. (2015). Pengaruh Kualitas Produk dan Kualitas Layanan Terhadap Keputusan Pembelian (Studi Kasus Pada Mebel CV Jati Endah Lodoyo Blitar). Riset Mahasiswa Ekonomi (RITMIK), 2(1), 89-110.

Nasution, \& Yasin. (2014). Pengaruh Promosi dan Harga Terhadap Minat Beli Perumahan Obama PT. Naila Adi Kurnia Sei Mencirim Medan. Jurnal Manajemen Dan Bisnis, 14(2).

Rezha, F. (2013). Analisis Pengaruh Kualitas Pelayanan Publik Terhadap Kepuasan Masyarakat (Studi Tentang Pelayanan Perekaman Kartu Tanda Penduduk Elektronik (KTP-el) di Kota Depok). Jurnal Administrasi Publik (JAP), 1(5). 
Setiadi, Nugroho, J. (2013). Perilaku Konsumen: Perspektif Kontemporer Pada Motif, Tujuan, dan Keinginan Konsumen. Kencana Prenada Media Group.

Sunarto. (2015). Pengaruh Kualitas Produk Terhadap Keputusan Pembelian Pada Toko Kerajinan Kulit Kartika Magetan. Equilibrium, 3(2), 191-205.

Tangkilisan, H. N. (2007). Manajemen Publik. Grasindo.

Utomo. (2009). Pengaruh Kualitas Layanan dan Kinerja Karyawan Terhadap Kepuasan Nasabah BPR Ukabima Grup. Universitas Pembangunan Nasional Veteran Yogyakarta.

Windarti, T., \& Ibrahim, M. (2017). Pengaruh Kualitas Produk Dan Kualitas Pelayanan Terhadap Kepuasan Konsumen Produk Donat Madu (Studi Pada Konsumen CV. Donat Madu Cihanjuang-Pekanbaru). Jom FISIP, 4(2). http://oreilly.com/catalog/errata.csp?isbn=9781449340377 